\title{
Transfer of the Agrobacterium tumefaciens TI Plasmid to Avirulent Agrobacteria and to Rhizobium ex planta
}

\author{
By P. J. J. HOOYKAAS, P. M. KLAPWIJK, M. P. NUTI, \\ R. A. SCHILPEROORT AND A. RÖRSCH \\ Department of Biochemistry, State University, Leiden, The Netherlands \\ (Received 19 July 1976; revised 27 September 1976)
}

\begin{abstract}
SUMMARY
A mutant of $A$. tumefaciens strain $\mathrm{B}^{6} \mathrm{~s}_{3}$, carrying the $\mathrm{R}$ factor $\mathrm{RP} 4$, was able to transfer its TI plasmid to various avirulent Agrobacterium strains and to a strain of Rhizobium. Strains carrying the TI $\left(\mathrm{B}_{6} \mathrm{~s} 3\right)$ plasmid were selected by their ability to utilize octopine. The isolates were able to induce tumours and exclude phage API. The tumours induced on Kalanchoë daigremontiana were rough and contained octopine. It was concluded that octopine utilization, phage exclusion, induction of rough tumours and synthesis of octopine in the tumours are determined by the $\mathrm{TI}\left(\mathrm{B}_{6} \mathrm{~S}_{3}\right)$ plasmid. Tumorigenicity was determined by this plasmid both in Agrobacteria and in Rhizobium, suggesting that all the genes necessary for tumour induction are plasmid-borne.
\end{abstract}

\section{INTRODUCTION}

The plant tumour, crown gall, can be induced on many dicotyledonous plants by inoculation of a wound site with Agrobacterium tumefaciens (Smith \& Townsend) Conn. The mechanism whereby the bacterium transforms normal cells into tumour cells is unknown (Drlica \& Kado, I975; Lippincott \& Lippincott, 1975; Schilperoort \& Bomhoff, 1975). It seems likely that genes located on a large bacterial plasmid (TI) are involved in the tumorigenicity since all virulent Agrobacterium strains contain the plasmid, while almost all avirulent strains lack it (Zaenen et al., I 974). Virulent strains become avirulent upon 'curing' of the plasmid (Van Larebeke et al., 1974), while avirulent strains become virulent when they receive it from a virulent donor strain (Van Larebeke et al., 1975; Watson et al., 1975).

Transfer of the TI plasmid has previously been reported only in mixed infections on the plant. In this paper we describe the ex planta transfer of it from a virulent, octopine-degrading Agrobacterium strain, harbouring the R factor RP4 (Datta et al., I97I ; Datta \& Hedges, 1972), to several avirulent recipient strains of Agrobacterium and to Rhizobium. The localization of some markers previously described as plasmid-borne, e.g. virulence, ability to utilize octopine or nopaline (Schilperoort et al., 1975; Watson et al., I975; Bomhoff et al., 1976), sensitivity to agrocin Kerr84 (Engler et al., 1975) and exclusion of phage APr (Van Larebeke et al., 1975; Schell, 1975) is discussed.

\section{METHODS}

Bacterial strains. Wild-type strains of Agrobacterium tumefaciens were: $\mathrm{B} 6$; $\mathrm{B} 6 \mathrm{~s}_{3}$; $\mathrm{s} 1005$; TR-I ; TR-6; C58; Ach-5; Ach-5-C3; 0362; 3/I; KerrI4 and T37 obtained from Dr J. Schell (Gent, Belgium); Kerr84 from Dr A. Kerr (Glen Osmond, Australia); E III 9.6.I from Laboratory of Microbiology, T.H.Delft, The Netherlands; IDI35 Ao from Dr C. I. Kado 
Table I. Strains of A. tumefaciens isolated in our laboratory

\begin{tabular}{|c|c|c|c|}
\hline LBA strain* & Origin & Markers & Known plasmids carried \\
\hline 33 & B $6 \mathrm{~s} 3 \times$ LBEI 316 & & RP4; TI(в6s3) \\
\hline 52 & в6s3 (mutagenized with NTG) & Met-Ile- $^{-}$ & $\mathrm{TI}(\mathrm{B} 6 \mathrm{~s} 3)$ \\
\hline 57 & LBA $52 \times$ LBA33 & $\mathrm{Met}^{-} \mathrm{Ile}^{-}$ & $\mathrm{RP}_{4} ; \mathrm{TI}\left(\mathrm{B} 6 \mathrm{~s}_{3}\right)$ \\
\hline 202 & $\mathrm{C} 58$ (heat treated at $37^{\circ} \mathrm{C}$ ) & & None \\
\hline $270 \dagger$ & $\begin{array}{l}\text { C58 (spontaneous mutant for } \\
\text { utilization of octopine) }\end{array}$ & $\begin{array}{l}\text { Utilization of } \\
\text { nopaline and } \\
\text { octopine }\end{array}$ & TI(C58) \\
\hline $601 t$ & LBA20 $2 \times$ LBA 57 & & $\mathrm{RP}_{4} ; \mathrm{TI}\left(\mathrm{B}_{633}\right)$ \\
\hline
\end{tabular}

(Davis, U.S.A.); and NCPPB396 from the National Collection of Plant Pathogenic Bacteria (Harpenden, Hertfordshire). Mutants of $A$. tumefaciens isolated in our laboratory are listed in Table I. Rhizobium trifolii strain 5 was obtained from the Rothamsted Collection of Rhizobium (Harpenden). Escherichia coli KI 2 pro met $(\lambda)$ (RP4) (LBEI3I6 in our collection) was received as strain J53(RP4) from Dr M. van Montagu (Gent, Belgium). All incubations were carried out at $29^{\circ} \mathrm{C}$.

Media. The rich medium (NB) contained $\left(\mathrm{g}^{-1}\right)$ : Difco nutrient broth, 8.0; Difco yeast extract, $5 \cdot 0 ; \mathrm{NaCl}, 5 \cdot 0$. Medium $\mathrm{LC}$, used in phage typing and tests of sensitivity to agrocin sio05, contained $\left(\mathrm{g}^{-1}\right)$ : Difco tryptone, 10.0; Difco yeast extract, 5.0; $\mathrm{NaCl}, 8 \cdot 0$. The minimal medium (SM) was that of Klapwijk et al. (1975); it was also used in tests of sensitivity to agrocin Kerr84 and agrocin NCPPB396. When SM was used for the selection of octopine-utilizing strains, ammonium sulphate was omitted (SM-N) and octopine was added to a final concentration of $100 \mathrm{mg} \mathrm{1}^{-1}$. Rhizobia were grown on YMB as a rich medium that contained ( $\mathrm{g}^{-1}$ ): mannitol, 10.0; Difco yeast extract, $0.4 ; \mathrm{NaCl}, 0 . \mathrm{I} ; \mathrm{MgSO}_{4} \cdot 7 \mathrm{H}_{2} \mathrm{O}$, $0.2 ; \mathrm{K}_{2} \mathrm{HPO}_{4}, 0.5 ; \mathrm{pH} \mathrm{6.8}$. The minimal medium for Rhizobium (RMM) contained $\left(\mathrm{g} \mathrm{l}^{-1}\right)$ : mannitol or glucose, I0.0; $\mathrm{KNO}_{3}, 0.6 ; \mathrm{CaCl}_{2} .2 \mathrm{H}_{2} \mathrm{O}, 0 . \mathrm{I} ; \mathrm{MgSO}_{4} \cdot 7 \mathrm{H}_{2} \mathrm{O}, 0.25 ; \mathrm{KH}_{2} \mathrm{PO}_{4}$, $\mathrm{I} \cdot 0 ; \mathrm{K}_{2} \mathrm{HPO}_{4}, \mathrm{I} \cdot 0 ; \mathrm{FeCl}_{3} \cdot 6 \mathrm{H}_{2} \mathrm{O}, 0.0 \mathrm{I}$; and $\left(\mu \mathrm{g} \mathrm{l}^{-1}\right): \mathrm{MnSO}_{4} \cdot \mathrm{H}_{2} \mathrm{O}, 20 ; \mathrm{ZnSO}_{4} \cdot 7 \mathrm{H}_{2} \mathrm{O}, 20$; $\mathrm{CuSO}_{4} \cdot 5 \mathrm{H}_{2} \mathrm{O}, 20 ; \mathrm{H}_{3} \mathrm{BO}_{3}, 20 ; \mathrm{CoCl}_{2}, 2 ; \mathrm{Na}_{2} \mathrm{MoO}_{4}, 20$; biotin, I0; calcium pantothenate, Io; thiamin, Io. When required, media were solidified with $\mathrm{I} \cdot 8 \%(\mathrm{w} / \mathrm{v})$ Difco Bacto-agar, or, when testing for utilization of octopine, with $2 \cdot 6 \%$ (w/v) Difco Special Agar Noble.

Mutagenesis and mutant isolation. $N$-Methyl- $N^{\prime}$-nitro- $N$-nitrosoguanidine (NTG) mutagenesis was as described by Klapwijk et al. (I975). Mutants were isolated after replica plating.

Plasmid transfer. Exponential-phase cultures of LBA57 and LBA202 in NB or SM, each containing $10^{9}$ bacteria $\mathrm{ml}^{-1}$, were mixed and $0.1 \mathrm{ml}$ was plated on $\mathrm{SM}$ plus carbenicillin (I00 $\mu \mathrm{g} \mathrm{ml}^{-1}$ ), SM-N plus octopine or SM-N plus octopine plus carbenicillin (100 $\mu \mathrm{g} \mathrm{ml}^{-1}$ ). After 2 days a layer of confluent growth had formed on the plates; from these a loopful of culture was inoculated into SM-N plus octopine. After these liquid cultures had reached the stationary phase, bacteria were plated, purified three times by single colony isolation and then characterized.

Phage sensitivity. Phage immunity patterns were determined by spotting small drops of phage lysates on double agar layers, consisting of bottom layers of $20 \mathrm{ml} \mathrm{I} \cdot 8 \%$ agar and top layers of $4 \mathrm{ml} 0.6 \%$ soft-agar, containing exponential-phase cultures of the bacteria to be tested. Exclusion of phage API was determined as described by Klapwijk et al. (I976). U5, a phage with a broad host-range specific for bacteria harbouring a plasmid of incompatibility class P, was obtained from Dr J. Schell (Gent, Belgium), as were phages SI, S2, $\mathrm{S}_{3}, \mathrm{~S}_{5}$, S6 and PS8vir. 
Agrocin sensitivity. Sensitivity to the agrocins produced by Agrobacterium strains sio05, TR-I, TR-6, Kerr84 and NCPPB396 was determined as described by Engler et al. (1975). For the determination of the sensitivity to agrocins of SI005, TR-I and TR-6 LC medium was used, while for that to the other agrocins SM medium was used.

Utilization of octopine and nopaline. This was determined by growing the bacteria in SM medium containing octopine or nopaline at a final concentration of $100 \mathrm{mg} \mathrm{l}^{-1}$. After $24 \mathrm{~h}$ incubation a small drop of the culture was spotted on to Whatman 3MM paper and stained for guanidines with the phenanthrenequinone reagent (Yamada \& Itano, I966).

Determination of octopine uptake was as described by Klapwijk et al. (1976).

Assay for virulence. Tumours were induced on stems of Kalanchoë daigremontiana (Hamet \& Perrier), and Nicotiana tabacum var. White Burley as described previously (Schilperoort, I969; Bomhoff et al., 1976). Tumours were induced on stems of Helianthus annuus var. giganteus by puncturing the stems with a sterile wooden pricker, the top of which had previously been dipped into a colony of the bacterium to be tested.

Detection of guanidines in tumours was as described by Schilperoort \& Bomhoff (1975).

Test of nodulation and nitrogen fixation. Enclosed cultures on seedling agar were carried out according to Vincent (I970); I 2 replicates on both Trifolium pratense cv.5I 23 and Trifolium parviflorum (kindly provided by Dr P. S. Nutman, Rothamsted, Harpenden) were examined for each test. Nodulation was scored after 4 weeks. Acetylene reduction by intact plants was measured in air containing $10 \%$ acetylene (Planqué \& Van Brussel, 1976); gas chromatography was carried out according to Citernesi et al., (1976).

Plasmid isolation. Plasmids were detected on alkaline sucrose gradients, using alkaline lysates of Agrobacteria (Ledeboer et al., 1976) or neutral lysates of Rhizobia (Nuti, unpublished results) labelled with $\left[{ }^{3} \mathrm{H}\right]$ thymidine. The plasmid nature of the peaks was always confirmed by renaturation kinetics (Ledeboer et al., 1976).

$B L$-test for the production of 3-ketoglycosides was as described by Bernaerts \& De Ley (I963).

Chemicals. NTG was obtained from Pfaltz \& Bauer, New York, U.S.A.; carbenicillin from Beecham, Heppi gnies, Belgium; $D(+)$-octopine from Sigma. Nopaline was extracted from plant tumours (Bomhoff et al., 1976). All other chemicals were of standard analytical grade.

\section{RESULTS}

\section{Plasmid transfer}

Overnight cultures of LBA52, LBA57 and LBA202 grown in NB were diluted I:20 in fresh medium and grown for 3 to $4 \mathrm{~h}$; they were then plated separately or mixed on the selective media, SM-N plus octopine, SM plus carbenicillin and SM-N plus octopine plus carbenicillin, and scored after 2 days incubation (Table 2). Only when both LBA57 and LBA202 were plated on the selective media was a thick layer of confluent growth observed. Plating of LBA2O2 in the presence or absence of LBA52 on SM-N plus octopine resulted in light growth, probably because the medium provided enough nitrogen to sustain some 'background' growth. From the above plates a loopful of culture was inoculated into SM-N plus octopine. Only when inocula were taken from plates on which both LBA57 and LBA202 were plated was growth observed in the liquid culture. Bacteria were isolated from stationary-phase cultures, purified three times by single colony isolation and then characterized. 
Table 2. Growth characteristics on selective media

$\begin{array}{lccc} & \text { SM+carbenicillin } & \text { SM-N + octopine } & \begin{array}{c}\text { SM-N+octopine } \\ + \text { carbenicillin }\end{array} \\ \text { LBA52 } & - & - & - \\ \text { LBA57 } & - & - & - \\ \text { LBA202 } & - & \pm & - \\ \text { LBA52 + LBA202 } & - & + & + \\ \text { LBA57+ LBA202 } & + & + & \end{array}$

\section{Properties of the exconjugants}

Since all the exconjugants ( 75 from 15 independent experiments) had the same properties, those of only one (LBA6OI) are recorded (Table 3). The phage and agrocin immunity pattern of LBA6OI is identical to that of LBA2O2. Unlike LBA2O2, LBA6OI is virulent, excludes phage API and metabolizes octopine. Moreover it has all known RP4 markers i.e. resistance to carbenicillin, kanamycin and tetracycline and sensitivity to the P-plasmid-specific phage $\mathrm{U}_{5}$. Alkaline sucrose gradients of a lysate of LBA60I revealed that it contains RP4 and a plasmid that is as large as the TI plasmid. Renaturation experiments showed that the large plasmid was identical to the TI(B6s3) plasmid. (The wild-type strain harbouring the plasmid is indicated in parentheses.) The restriction pattern of the plasmid was similar to that of the TI(B6s3) plasmid, but different from the TI(C58) plasmid (J. Schell, personal communication). This showed that we had transferred the TI(в6s3) plasmid ex planta from LBA57 to LBA202 and that genes involved in the breakdown of octopine and in exclusion of phage API are located on it. LBA60r, like LBA57, induced tumours on Kalanchoë daigremontiana that contain octopine and have a rough surface with roots all over them, while $\mathrm{c} 58$, the parent strain of LBA202, induces tumours which contain nopaline and have a smooth surface with roots only at the bottom of the tumour (Fig. I). Apparently the plasmid determines the type of tumour that will develop irrespective of the chromosomal background.

\section{Transfer of the TI plasmid to other recipients and properties of the exconjugants}

The $\mathrm{TI}(\mathrm{B} 6 \mathrm{~s} 3)$ plasmid was transferred by the procedure described above to Ach-5-C3, a derivative of Ach- 5 cured from its TI plasmid by growth at $37^{\circ} \mathrm{C}$. This hcst also acquired the abilities to induce rough tumours containing octopine on Kalanchoë daigremontiana and to break down octopine. We were unable to transfer the plasmid to $A$. tumefaciens strains Sro05, TR-I and TR-6, probably because these strains produce an agrocin to which the donor is sensitive.

The TI(B6s3) plasmid was transferred from LBA57 to Rhizobium trifolii strain 5. Rhizobium, like all Agrobacterium recipients, gained the ability to induce tumours and to metabolize octopine (Table 4). The exconjugant (LPR5OI) was shown to be a $R$. trifolii strain by its inability to grow on NB and LC, its negative response in the BL-test, and its ability to form nitrogen-fixing nodules on Trifolium pratense. Unexpectedly, LPR5OI was not able to nodulate $T$. parviflorum. Alkaline sucrose gradients revealed that $R$. trifolii strain 5 contains a plasmid of its own which is considerably larger than the TI(B6s3) plasmid (Nuti, unpublished results). The exconjugant, however, only carries a plasmid of the size of the TI(B6s3) plasmid. Thus, either $R$. trifolii had lost its own large plasmid after introduction of the $\mathrm{TI}(\mathrm{B} 6 \mathrm{~s} 3)$ plasmid, or a recombinant plasmid was formed. 


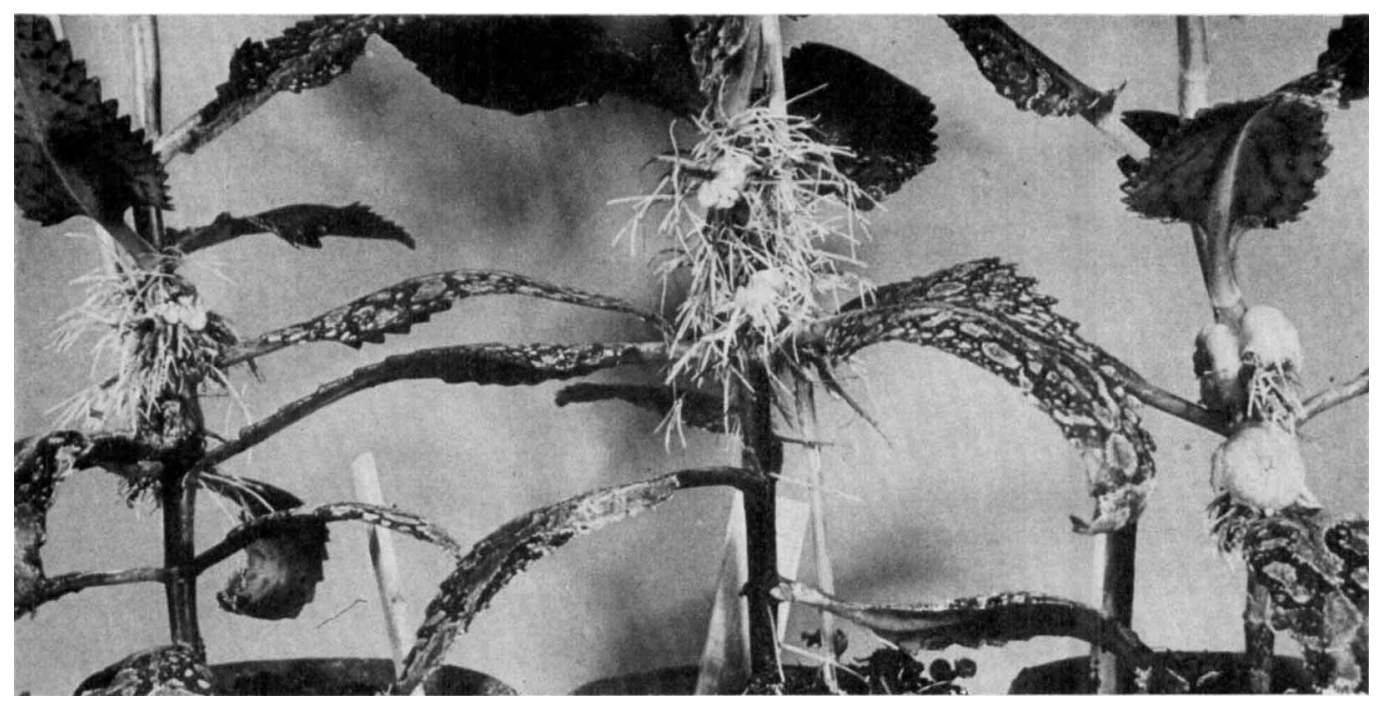

Fig. I. Virulence tests on Kalanchoё daigremontiana with (left) B6s3, (centre) LBA60 I and (right) C58. Note the tumour morphology : rough tumours with roots all over them for B6s3 and LBA60I, smooth tumours with root formation only at the bottom of the tumour for $\mathrm{c}_{5} 8$.

Table 3. Properties of LBA60 I compared with donor (LBA57) and recipient (LBA2O2) strain and some reference strains

Growth on SM

Growth on SM-N

+ octopine

Utilization of octopine

Utilization of nopaline

Sensitivity to:

Phage SI

Phage S2

Phage $S_{3}$

Phage $\mathrm{S}_{5}$

Phage S6

Phage PS8vir

Agrocin $\mathrm{SIO05}$

Agrocin NCPPB 396

Agrocin Kerr84

Virulence

Guanidines in tumour

Tumour morphology

Sensitivity to phage API

Exclusion of phage API

Presence of a large plasmid

Resistance to:

Carbenicillin

(100 $\mu \mathrm{g} \mathrm{ml}^{-1}$ )

Kanamycin ( $\left.50 \mu \mathrm{g} \mathrm{ml}^{-1}\right)$

Tetracycline $\left(2 \mu \mathrm{g} \mathrm{ml}^{-1}\right)$

Sensitivity to phage $U_{5}$

\begin{tabular}{|c|c|c|c|c|c|}
\hline \multicolumn{6}{|c|}{ Strain } \\
\hline B6s3 & LBA57 & LBA2O2 & LBA60I & C58 & LBA270 \\
\hline+ & - & + & + & + & + \\
\hline+ & - & - & + & - & + \\
\hline+ & + & - & + & - & + \\
\hline- & - & - & - & + & + \\
\hline - & _ & - & - & - & _ \\
\hline - & - & + & + & + & + \\
\hline+ & + & - & - & - & - \\
\hline- & - & + & + & + & + \\
\hline - & - & + & + & + & + \\
\hline+ & + & - & - & - & - \\
\hline+ & + & - & - & - & - \\
\hline- & - & - & - & + & + \\
\hline - & - & - & - & + & + \\
\hline 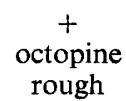 & $\underset{\substack{+ \\
\text { octopine } \\
\text { rough }}}{+}$ & - & $\begin{array}{c}+ \\
\text { octopine } \\
\text { rough }\end{array}$ & $\begin{array}{c}+ \\
\text { nopaline } \\
\text { smooth }\end{array}$ & $\begin{array}{c}+ \\
\text { nopaline } \\
\text { smooth }\end{array}$ \\
\hline+ & + & + & + & + & + \\
\hline+ & + & - & + & + & + \\
\hline id + & + & - & + & + & + \\
\hline- & + & - & + & - & - \\
\hline - & + & - & + & - & - \\
\hline- & + & - & + & - & - \\
\hline- & + & - & + & - & - \\
\hline
\end{tabular}


Table 4. Properties of the exconjugant $R$. trifolii LPR5OI compared with the donor A. tumefaciens LBA57 and recipient $R$. trifolii 5

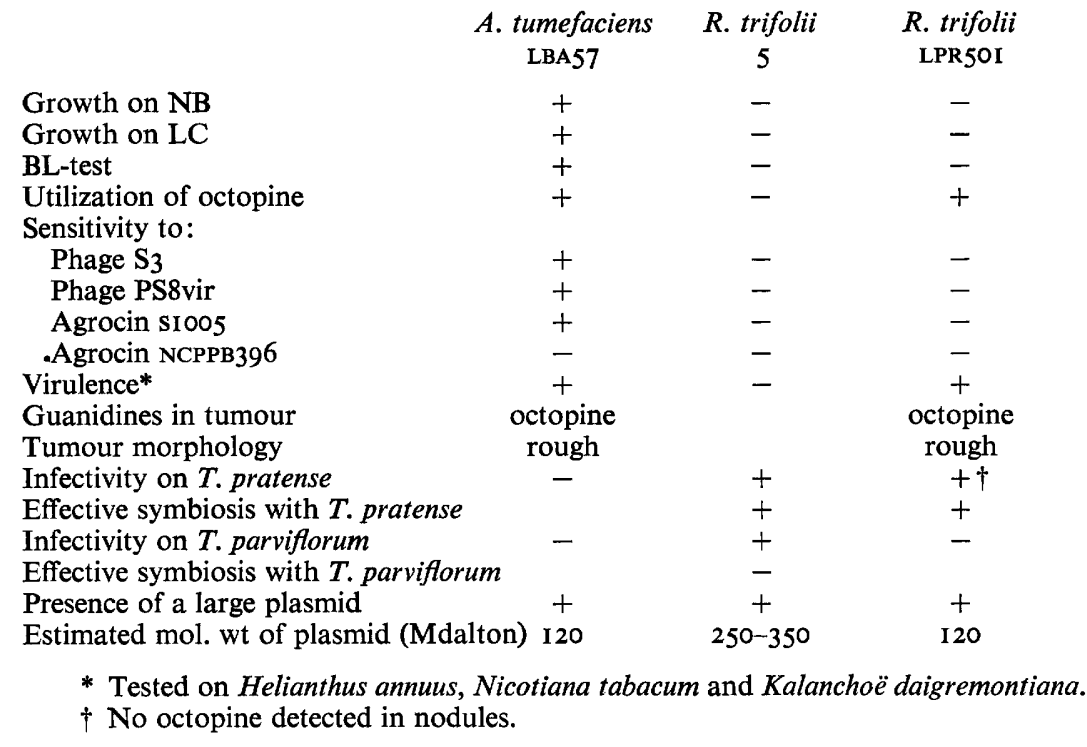

\section{Virulent strains as recipients in transfer-experiments}

When avirulent, plasmid-less strains of $A$. tumefaciens like LBA202 and sio05 were plated alone on SM-N plus octopine light growth was observed, but when virulent, nopalinedegrading strains (C58, E III 9.6.I, 0362, 3/I, KerrI4, T37 and IDI35 AO) were plated on the same medium a number of colonies always appeared in a background of light growth. The bacteria in these colonies were mutants able to break down nopaline as well as octopine. In these mutants the permease for the uptake of octopine and nopaline was constitutive, whereas it had to be induced by nopaline in the wild-type strains (Klapwijk, unpublished results).

When virulent, nopaline-degrading strains were used as recipients for the TI(B6s3) plasmid, strains were found that were able to metabolize both octopine and nopaline. Unlike avirulent recipients which received the $\mathrm{TI}\left(\mathrm{B}_{6} \mathrm{~s} 3\right)$ plasmid, these strains induced smooth, nopaline-containing tumours on Kalanchoë daigremontiana. Thus, the isolates were probably not exconjugants, but spontaneous mutants of the type described above.

\section{DISCUSSION}

Transfer of the $\operatorname{TI}\left(\mathrm{B}_{6} \mathrm{~s} 3\right)$ plasmid is observed only if relatively large numbers of parental bacteria are brought together on a solid medium and exconjugants can only be isolated from the layer of confluent growth. Thus the frequency of transfer cannot be determined quantitatively. In several experiments, confluent growth was less heavy and 10 to 20 clearly distinguishable recombinant colonies were observed. As $10^{8}$ parental bacteria were added per plate the frequency of transfer is about $10^{-7}$, or less if the parental bacteria need to multiply before transfer is possible.

The role of the plasmid RP4 in the ex planta transfer of the TI plasmid is uncertain. Our results suggest that $\mathrm{RP}_{4}$ is involved in the mobilization of the plasmid. All the strains which had received the TI plasmid, also received RP4. Also, transfer of the TI plasmid from strain 
LBA52, which is isogenic with LBA57 except for its lack of RP4, was not observed. Transfer of the TI plasmid of some nopaline-utilizing strains has been reported to occur in the absence of RP4 in a mixed infection on the plant (Van Larebeke et al., 1975; Watson et al., 1975). The TI plasmids may have fertility functions which are only expressed in the presence of some plant components.

Our results clearly demonstrate that genes involved in the metabolism of octopine are located on the TI(в6s3) plasmid. Klapwijk et al. (1976) suggested that at least three genes are involved in the metabolism of octopine: a regulator gene $(u a d R)$, a permease gene $(u a d B)$ and an oxidase gene (uadA). Permease-tests with LBA60I revealed that at least the regulator gene and the permease gene are located on the TI(B6s3) plasmid (Klapwijk, unpublished results). Since Rhizobium could utilize octopine after introduction of the TI(B6s3) plasmid, we conclude that the oxidase gene is of plasmid origin, unless such a gene was present in Rhizobium. Our results show that genes which determine the morphology of the tumour and the synthesis of octopine or nopaline in the tumour are also located on the TI plasmid.

Strain C5$_{8}$ excludes phage API, while the cured derivative, LBA202, does not (Van Larebeke et al., 1975; Schell, I975). We have shown that LBA6oI also excludes phage API, therefore a locus responsible for the exclusion of phage API is present both on the TI(B6s3) plasmid and the TI(C58) plasmid. A locus for sensitivity to agrocin Kerr84 is located on the TI(C58) plasmid (Engler et al., I975), but the locus for sensitivity to agrocin SI 005 seems to be chromosomal, since LBA60I is insensitive to the agrocin, whereas the donor strain LBA57 is sensitive. While $\mathrm{C} 58$ can be cured of its plasmid by growth at $37^{\circ} \mathrm{C}$, LBA60 I does not lose its plasmid by growth at the same temperature. Thus, as was stated by Watson et al. (1975), a locus on the TI(C58) plasmid is probably responsible for curing by growth at $37^{\circ} \mathrm{C}$.

Rhizobium trifolii strain 5, like Agrobacterium recipients, acquired the ability to break down octopine and to induce tumours on introduction of the TI(в6s 3 ) plasmid. Although the reason for loss of infectivity on $T$. parviflorum remains obscure, the exconjugant had not lost the ability to form effective nodules on $T$. pratense. The observation that Rhizobium became tumorigenic on the introduction of the TI plasmid suggests that the plasmid DNA of strain $\mathrm{B} 6 \mathrm{~s} 3$ itself or some of its gene products are sufficient for the induction of tumours.

We are grateful to Dr A. M. Ledeboer for carrying out plasmid isolations. This work was sponsored by the Netherlands Foundation for Chemical Research (SON) with financial aid from the Netherlands Organization for the Advancement of Pure Scientific Research (ZWO). Part of it was supported by EEC contract 044I. M. P. Nuti was on leave from the Institute of Agrarian Microbiology, University of Pisa, Italy, with a NATO-CNR fellowship.

\section{REFERENCES}

Bernaerts, M. \& DE LEY, J. (1963). A biochemical test for crown gall bacteria. Nature, London I97, $406-407$. Bomhoff, G. H., Klapwijk, P. M., Kester, H. C. M., Schilperoort, R. A., Hernalsteens, J. P. \& Schell, J. (1976). Octopine and nopaline: synthesis and breakdown genetically controlled by a plasmid of Agrobacterium tumefaciens. Molecular and General Genetics 145, I77-1 81 .

Citernesi, U., Neglia, R., Seritti, A., LePidi, A. A., FilipPi, C., Bagnoli, G. \& Nuti, M. P. (1976). Nitrogen-fixing bacteria in the gastroenteric cavity of soil animals. Soil Biology and Biochemistry (in the Press).

DAtTA, N. \& Hedges, R. W. (I972). Host ranges of R factors. Journal of General Microbiology 70, 453-460.

Datta, N., Hedges, R. W., Shaw, E. J., Sykes, R. B. \& Richmond, M. H. (I97I). Properties of an R factor from Pseudomonas aeruginosa. Journal of Bacteriology 108, I 244-1 249.

DrLiCA, K. A. \& KaDo, C. I. (I975). Crown gall tumors: are bacterial nucleic acids involved ? Bacteriological Reviews 39, 186-196. 
Engler, G., Holsters, M., van Montagu, M., Schell, J. Hernalsteens, J. P. \& Schilperoort, R. A. (1975). Agrocin 84 sensitivity, a plasmid determined property. Molecular and General Genetics $\mathbf{1 3 8}$, 345-349.

KlapwiJk, P. M., de Jonge, A. J. R., Schilperoort, R. A. \& Rörsch, A. (1975). An enrichment technique for auxotrophs of Agrobacterium tumefaciens using a combination of carbenicillin and lysozyme. Journal of General Microbiology 91, 177-182.

Klapwijk, P. M., Hooykaas, P. J. J., Kester, H. C. M., Schilperoort, R. A. \& Rörsch, A. (I976). Isolation and characterization of Agrobacterium tumefaciens mutants affected in the utilization of octopine, octopinic acid and lysopine. Journal of General Microbiology 96, 155-163.

Larebeke, N. van, Engler, G., Holsters, M., van den Elsacker, S., Zaenen, I., Schilperoort, R. A. \& SCHELL, J. (1974). Large plasmid in Agrobacterium tumefaciens essential for crown gall inducing ability. Nature, London 252, I69-I 70.

Larebeke, N. van, Genetello, Ch., Schell, J., Schilperoort, R. A., Hermans, A. K., Hernalsteens, J. P. \& van Montagu, M. (1975). Acquisition of tumor inducing ability by non-oncogenic Agrobacteria as a result of plasmid transfer. Nature, London $\mathbf{2 5 5}, 742-743$.

Ledeboer, A. M., Krol, A. J. M., Dons, J. J. M., Spier, F., Schilperoort, R. A., Zaenen, I., van Larebeke, N. \& SCHell, J. (1976). On the isolation of TI plasmid from Agrobacterium tumefaciens. Nucleic Acids Research 3, 449-464.

Lippincott, J. A. \& Lippincott, B. B. (1975). The genus Agrobacterium and plant tumorigenesis. Annual Review of Microbiology 29, 377-405.

Planqué, K. \& VAN Brussel, A. A. N. (1976). An improved large scale isolation procedure for bacteroids of Rhizobium leguminosarum Frank. from Pisum sativum L. Plant and Soil 45, 309-31 5.

SCHELl, J. (1975). The role of plasmids in crown-gall formation by Agrobacterium tumefaciens. In Genetic Manipulations with Plant Material, pp. I63-181. Edited by L. Ledoux. New York: Plenum Press.

SchilperoORT, R. A. (1969). Investigations on plant tumors. Crown gall. On the biochemistry of tumor induction by Agrobacterium tumefaciens. Thesis, State University, Leiden, The Netherlands.

Schilperoort, R. A. \& BomнofF, G. H. (1975). Crown gall: a model for tumor research and genetic engineering. In Genetic Manipulations with Plant Material, pp. I41-162. Edited by L. Ledoux. New York: Plenum Press.

Schilperoort, R. A., Kester, H. C. M., KlapwiJk, P. M., Rörsch, A. \& Schell, J. (1975). Plant tumors induced by $A$. tumefaciens. A genetic approach. In Semaine d'Étude Agriculture et Hygiène des Plants, pp. 25-35. Edited by P. Martens. Gembloux, Belgium: Faculté des Sciences Agronomiques de l'État et Centre de Recherches Agronomiques.

Vincent, J. M. (1970). A Manual for the Practical Study of Root-nodule Bacteria, I.B.P. Handbook no. I5, pp. 75-82. Oxford: Blackwell Scientific Publications.

Watson, B., Currier, T. C., Gordon, M. P., Chilton, M. D. \& Nester, E. W. (1975). Plasmid required for virulence of Agrobacterium tumefaciens. Journal of Bacteriology 123, 255-264.

YamadA, S. \& ITANO, H. A. (1966). Phenanthrene quinone as an analytical reagent for arginine and other mono-substituted guanidines. Biochimica et biophysica acta 130, 538-540.

Zaenen, I, van Larebeke, N., Teuchy, H., van Montagu, M. \& Schell, J. (I974). Supercoiled circular DNA in crown gall inducing Agrobacterium strains. Journal of Molecular Biology 86, I09-I27. 